Nat. Hazards Earth Syst. Sci. Discuss., https://doi.org/10.5194/nhess-2018-13

Manuscript under review for journal Nat. Hazards Earth Syst. Sci.

Discussion started: 23 January 2018

(c) Author(s) 2018. CC BY 4.0 License.

\title{
The Role of Unmanned Aerial Vehicles (UAVs) In Monitoring Rapidly Occuring Landslides
}

\author{
Servet Yaprak $^{1}$, Omer Yildirim ${ }^{1}$, Tekin Susam ${ }^{1}$, Samed Inyurt ${ }^{2}$ Irfan \\ Oguz $^{1}$ \\ ${ }^{1}$ Geomatics Engineering, Gaziosmanpaşa University, Tokat, Turkey \\ ${ }^{2}$ Geomatics Engineering, Bulent Ecevit University, Zonguldak Turkey \\ Corresponding author: Samed INYURT,e-mail:samed_inyurt@hotmail.com
}

\begin{abstract}
This study used the Unmanned Aerial Vehicle (UAV), which was designed and produced to monitor rapidly occurring landslides in forest areas. It was aimed to determine the location data for the study area using image sensors integrated into the UAV. The study area was determined as the landslide sites located in the Taşlıçiftlik Campus of Gaziosmanpaşa University, Turkey. It was determined that landslide activities were on going in the determined study area and data was collected regarding the displacement of materials. Additionally, it was observed that data about landslides may be collected in a fast and sensitive way using UAVs, and this method is proposed as a new approach. Flights took place over a total of five different periods. In order to determine the direction and coordinate variables for the developed model, eight Ground Control Points (GCPs), whose coordinates were obtained with the GNSS method, were placed on the study area. In each period, approximately 190 photographs were investigated. The photos obtained were analysed using the PIX4D software. At the end of each period, the RMS and Ground Sample Distance (GSD) values of the GCPs were calculated. Orthomosaic and Digital Surface Models (DSM) were produced for the location and height model. The results showed that $\max \mathrm{RMS}= \pm 3.3 \mathrm{~cm}$ and $\max$ $\mathrm{GSD}=3.57 \mathrm{~cm} / 1.40 \mathrm{in}$. When the first and fifth periods are compared; the highest spatial displacement value $\Delta \mathrm{S}=111.0 \mathrm{~cm}$, the highest subsidence value $\Delta \mathrm{h}=37.3 \mathrm{~cm}$ and the highest swelling value $\Delta \mathrm{h}=28.6 \mathrm{~cm}$ as measured.
\end{abstract}

Keywords: Unmanned Aerial Vehicles (UAV); landslides; ground sample distance (GSD); digital surface model (DSM); orthomosaic

\section{Introduction}

Landslides are a worldwide phenomenon that create dramatic physical and economic effects and sometimes lead to tragic deaths. During landslides two main factors occur, which are human and environmental effects. The human factors may be controlled; however, it is very difficult to control the topography and soil structure (Turner et al., 2015). Thus, landslides cause disasters on a global scale each year. These disasters are increasing in number due to the incorrect usage of the land. The main reason for the increase in landslide disasters is the instability of the soil and erodibility on the surface. Surface soil erodibility takes place as a result of various issues, such as deforestation, an increase in consumption by an increasingly larger population, uncontrolled land usage, etc. (Nadim et al., 2006). Landslides are primarily disasters that take place in mountainous and sloped areas around the world (Dikau et al., 1996). Landslides do not always show characteristic occurrences, however, they are usually triggered by increased stress on sloped surfaces. This triggering can occur faster because of short or long periods of heavy rain, earthquakes, or subterranean activity (Lucier et al., 2014). During landslide monitoring, a number of factors need to be continuously assessed, including the: extent 
Nat. Hazards Earth Syst. Sci. Discuss., https://doi.org/10.5194/nhess-2018-13

Manuscript under review for journal Nat. Hazards Earth Syst. Sci.

Discussion started: 23 January 2018

(c) Author(s) 2018. CC BY 4.0 License.

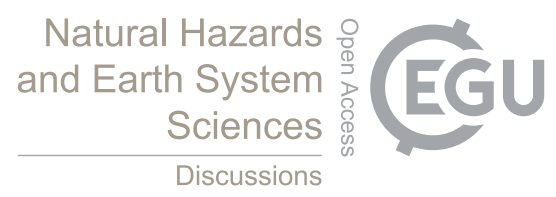

47

48

49

50

51

52

53

54

55

56

57

58

59

60

61

62

63

64

65

66

67

68

69

70

71

72

73

74

75

76

77

78

79

80

81

82

of the landslide, detection of fissure structures, topography of the land and rate of displacements that could be related to fracture (Niethammer et al., 2010). Understanding the mechanism of landslides may be made easier by being able to measure the vertical and horizontal displacements. This is possible by forming a Digital Surface Model (DSM) of the landslide area.

The calculation of displacements by Differential GPS (DGPS), total station, airborne Light Detection and Ranging (LIDAR) and Terrestrial Laser Scanner (TLS) techniques have been used since the beginning of the 2000s (Nadim et al., 2006). Additionally, remote sensing has been put into operation in combination with other techniques (Mantovani et al., 1996). There are several platforms, which are used to monitor landslide occurrences via the method of remote sensing, where displacement data can be collected. These include remote sensing satellites, manned aerial vehicles, specially equipped land vehicles and, as a new method, Unmanned Aerial Vehicles (UAV) (Rau et al., 2011). These UAV are aerial vehicles that are able to fly without crew automatically or semiautomatically based on aerodynamics principles. UAV systems have become popular in solving problems in various fields and applications (Saripalli et al., 2003; Tahar et al., 2011). In parallel with the developing technology, UAVs have been used in recent years in integration with the Global Positioning System (GPS), Inertial Measurement Units (IMU) and high definition cameras and they have also been used in remote sensing (RS), digital mapping and photogrammetry in scientific studies. While satellites and manned aerial vehicles are able to gather location data in high resolutions of $20-50 \mathrm{~cm} / \mathrm{pixel}$, UAVs are able to obtain even higher resolutions of $1 \mathrm{~cm} /$ pixel, as they are able to fly at lower altitudes (Hunt et al., 2010). Indeed, UAV Photogrammetry opens up various new applications in close-range photogrammetry in the geomatics field (Eisenbeiss 2009). Monitoring landslides using UAV systems is an integrated process involving ground surveying methods and aerial mapping methods. All measurement devices that require details are integrated to UAVs, which fly at lower altitudes than satellites or planes. All positional data are collected safely from above, except for determining and measuring the control points (Nagai et al., 2008).

This study was conducted in the landslide site at the Organized Industrial Zone near a campus of Gaziosmanpaşa University. The area of the studied field was approximately 50 hectares. The Multicopter was produced by the Department of Geomatics Engineering at Gaziosmanpaşa University (GOP) and the firm TEKNOMER was used for this study. A Sony Alpha 6000 (Ilce 6000) camera, IMU and GPS systems, produced for moving platforms, were integrated to the UAV. Five different flights took place on different dates in the study area and an average of 290 photographs were obtained on each flight. Eight ground control points (GCPs), which were well distributed over the data area, were set up in the landslide area (Figure 6). The positional information about the ground control points was collected using four dual-frequency Geodesic GNSS receivers (Trimble, Topcon). Two hours of static GNSS measurements were analyzed in 3D using the Leica LGO V.8.3 software in connection to the TUSAGA Active System.

\section{System Design}


Nat. Hazards Earth Syst. Sci. Discuss., https://doi.org/10.5194/nhess-2018-13

Manuscript under review for journal Nat. Hazards Earth Syst. Sci.

Discussion started: 23 January 2018

(c) Author(s) 2018. CC BY 4.0 License.
Natural Hazards

and Earth System

Sciences

Discussions
90

91

92

93

100

101

102

103

104

105

106

107

108

109

This study used the multicopter, which was produced by the department of Geomatics Engineering at Gaziosmanpaşa University (GOP) (Figure 1a and b). The designed multicopter consisted of a platform and camera systems.

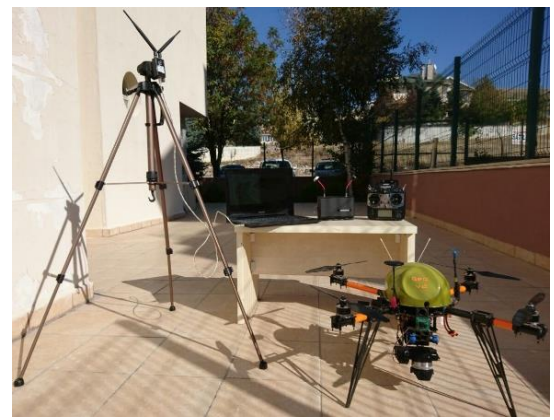

Figure 1a. The UAV and environmental components

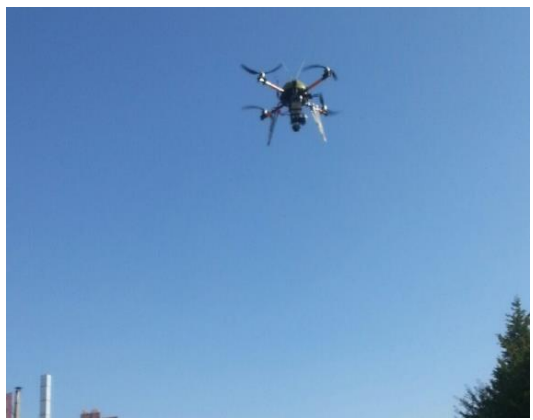

Figure $1 b$. The UAV in the air

\subsection{UAV Platform}

UAV platforms provide crucial alternative solutions for environmental research (Nex and Remondino, 2014). The UAV environmental components used in this study were integrated into the multicopter as seen Figure 2. The platform had a blade-span of $0.80 \mathrm{~m}$, height of $0.36 \mathrm{~m}$, weight of $4.4 \mathrm{~kg}$ and operating weight of $5 \mathrm{~kg}$. All sensors were placed on the carrying platform to achieve operating integrity. The carrying platform operated at the speed of $14 \mathrm{~m} / \mathrm{sec}$ while shooting photos. The multicopter had a stabilized camera gimbal to take nadir photos during the flight. The characteristics of the carrying platform are given in Table 1.

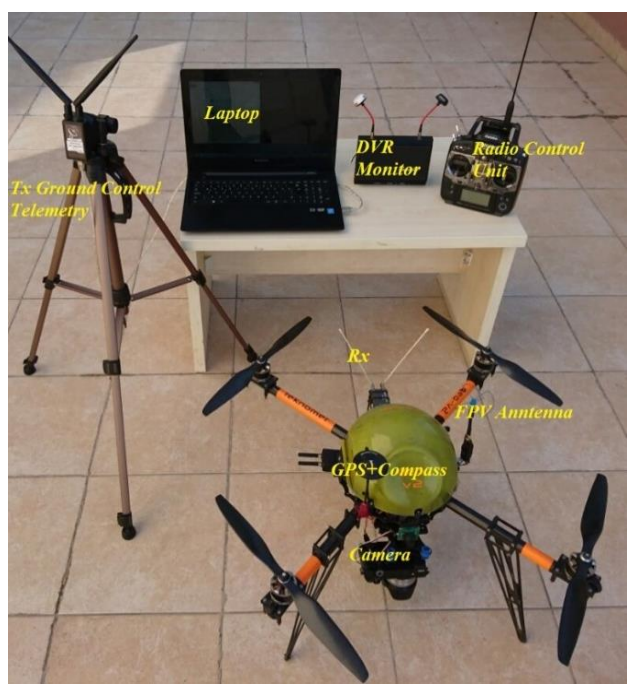

Figure 2. UAV environmental components 
Nat. Hazards Earth Syst. Sci. Discuss., https://doi.org/10.5194/nhess-2018-13

Manuscript under review for journal Nat. Hazards Earth Syst. Sci.

Discussion started: 23 January 2018

(c) Author(s) 2018. CC BY 4.0 License.

Table 1. Platform technical specifications

\begin{tabular}{ll}
\hline Specification & Technical Details \\
\hline Weight & $4.3 \mathrm{~kg}$ \\
Wing Span & $74 \mathrm{~cm}$ \\
Payload & $4 \mathrm{~kg}$ \\
Height & $34 \mathrm{~cm}$ with GPS Antenna \\
Range & $4 \mathrm{~km}$ \\
Endurance & $30 \mathrm{~min}$ \\
Speed & $14 \mathrm{~m} / \mathrm{sec}$ \\
Maximum Speed & $70 \mathrm{~km}-30 \mathrm{~mm} / \mathrm{sec}$ \\
Radio Control & $433 \mathrm{MHz}$ \\
Frame Transponder (FPV) & $2.4 \mathrm{GHz}$ \\
Telemetry Radio & $868 \mathrm{MHz}$ \\
GPS & $5 \mathrm{~Hz}-72$ channels \\
Battery & $6 \mathrm{~S} \mathrm{li-po} \mathrm{25C} \mathrm{1600} \mathrm{Mah}$ \\
Monitor & $40 \mathrm{Channels} \mathrm{5.8} \mathrm{GHz} \mathrm{DVR} \mathrm{7} \mathrm{inch} \mathrm{LED}$ \\
& system \\
Gimbal & Mapping Gimbal \\
Motors & $35 \times 15 \mathrm{Brushless} \mathrm{Motor}$ \\
Frame & $22 \mathrm{~mm} 3 \mathrm{~K}$ Carbon \\
ESC & $60 \mathrm{Ampere} 400 \mathrm{~Hz}$ \\
Prop & $15 \times 55$ inch Carbon \\
\hline
\end{tabular}

\subsection{Camera System}

In this study, a Sony ILCE-6000 E16mm F2.8-16.0-6000x4000 (RGB) camera was used for collecting visible imagery (Figure 3). Table 2 shows the characteristics of the camera. The main controller of the UAV was programmed to shoot photos regularly, every two seconds. This way, the shutter of the camera was triggered at the desired frequency intervals.

The camera and the main flight controller card were connected using a special cable. Vibration isolation materials were used between the camera and the UAV to prevent the effects of flight vibrations on the camera. During the flight, all photos were taken in the RAW format and stored in the memory of the camera. 
Nat. Hazards Earth Syst. Sci. Discuss., https://doi.org/10.5194/nhess-2018-13

Manuscript under review for journal Nat. Hazards Earth Syst. Sci.

Discussion started: 23 January 2018

(c) Author(s) 2018. CC BY 4.0 License.
Natural Hazards

and Earth System

Sciences

Discussions

\begin{tabular}{|c|c|}
\hline Property & Technical Detail \\
\hline Dimensions & $4.72 \times 2.63 \times 1.78$ in \\
\hline Weight & $10.05 \mathrm{oz}$ (Body Only) / $12.13 \mathrm{oz}$ (with battery and media) \\
\hline Megapixels & $12 \mathrm{MP}$ \\
\hline Sensor Type & APS-C \\
\hline Sensor Size & APS-C type $(23.5 \times 15.6 \mathrm{~mm})$ \\
\hline Number of pixels (effective) & $24.3 \mathrm{MP}$ \\
\hline Number of pixels (total) & Approx. 24.7 megapixels \\
\hline $\begin{array}{l}\text { ISO sensitivity (recommended } \\
\text { exposure index) }\end{array}$ & ISO $100-25600$ \\
\hline Clear image zoom & Approx. $2 \mathrm{x}$ \\
\hline Digital zoom (still image) & L: Approx. 4x; M: Approx. 5.7x;S: Approx. 8x \\
\hline LCD Size & 3.0 in wide type TFT LCD \\
\hline LCD Dots & 921,600 dots \\
\hline Viewfinder Type & 0.39 in-type electronic viewfinder (colour) \\
\hline Shutter speed & $\begin{array}{l}\text { Still images: } 1 / 4000 \text { to } 30 \mathrm{sec} \text {, Bulb, Movies: } 1 / 4000 \text { to } 1 / 4(1 / 3 \\
\text { steps) up to } 1 / 60 \text { in AUTO mode (up to } 1 / 30 \text { in Auto slow shutter } \\
\text { mode) }\end{array}$ \\
\hline Flash sync. Speed & $1 / 160 \mathrm{sec}$. \\
\hline
\end{tabular}

136

137

138

139

140

141

142

143

144

145

\section{Study Area}

This study was carried out in order to monitor the landslides with UAV in Tokat Province. The study area was selected to track the landslides that began in the area where factories and industrial enterprises are located. There is a great landslide risk in this industrial area, it is a preexisting situation and if the motion continues or accelerates it could mean great danger for the nearby factories. For this reason, the movement needs to be monitored.

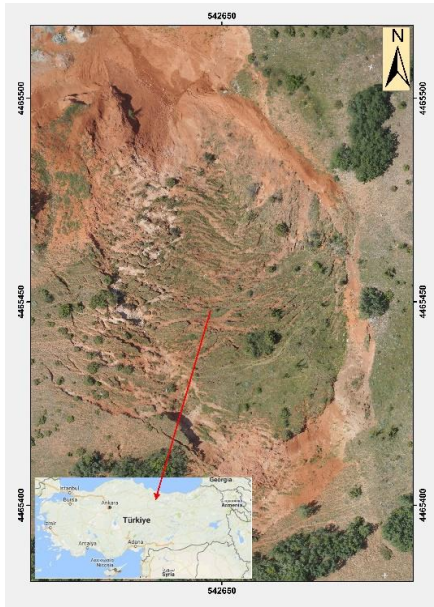


Nat. Hazards Earth Syst. Sci. Discuss., https://doi.org/10.5194/nhess-2018-13

Manuscript under review for journal Nat. Hazards Earth Syst. Sci.

Discussion started: 23 January 2018

(c) Author(s) 2018. CC BY 4.0 License.

Figure 4. The study area

Table 3. Some soil properties of the study area

\begin{tabular}{lllllllll}
\hline $\begin{array}{l}\text { Study } \\
\text { Site }\end{array}$ & $\begin{array}{l}\text { Soil Depth } \\
(\mathrm{m})\end{array}$ & $\begin{array}{l}\text { Tlay } \\
\%\end{array}$ & Sand \% & $\begin{array}{l}\text { Silt } \\
\%\end{array}$ & Class & $\begin{array}{l}\text { Coarse } \\
\text { Material } \\
\%\end{array}$ & $\begin{array}{l}\text { Aggregate } \\
\text { Stability } \\
\%\end{array}$ & $\begin{array}{l}\text { Dispersion } \\
\text { Ratio } \\
\%\end{array}$ \\
\hline 1 & $0.0-0.2$ & 40.0 & 28.7 & 31.3 & CL & 13.0 & 34.3 & 36.9 \\
& $0.2-0.4$ & 37.5 & 31.2 & 31.3 & CL & 31.0 & 41.3 & 60.0 \\
2 & $0.0-0.2$ & 50.0 & 11.2 & 38.8 & C & 4.2 & 13.9 & 57.8 \\
& $0.2-0.4$ & 52.5 & 11.2 & 36.3 & C & 19.7 & 46.2 & 49.3 \\
3 & $0.0-0.2$ & 40.0 & 13.7 & 46.3 & SiL & 15.7 & 18.8 & 36.3 \\
& $0.2-0.4$ & 42.5 & 13.7 & 43.8 & SiL & 6.6 & 13.1 & 47.9 \\
\hline
\end{tabular}

The coordinates of the landslide area used for the study are given as $40^{\circ} 19^{\prime} 20.8^{\prime \prime}$ N, $36^{0} 30^{\prime}$ 0.6” E. The study area is shown in Figure 4.

\subsection{Soil Properties of the Study Area}

The oldest layer at the research area is Paleozoic aged metaophiolite (Metadunite, amphibolite/Metagabbro). The sedimentary layer, which is called eosin aged "Çekerek formation", is over the metaophiolite layer. This formation consists of sandstone, pebble, silt and clay (Sumengen, 1998).

Soil samples were collected from three different locations at 0-0.2 and 0.2-0.4 m depths and analyzed for soil particle distribution using the Bouyoucos hydrometer method (Gee and Bauder, 1986). The fraction greater than $2 \mathrm{~mm}$ diameter was separated and reported as coarse material (Gee and Bauder, 1986). The dispersion ratio was calculated using Equation 1 (Middleton 1930). The aggregate stability index was calculated by the wet sieving method (Yoder 1936).

$$
\text { Dispersion Ratio }=\{\mathrm{D}(\text { Silt }+ \text { Clay }) / T(\text { Silt }+ \text { Clay })\} \times 100
$$

Where D is dispersed silt + clay after $1 \mathrm{~kg}$ of oven-dried soil in a litre of distilled water was shaken 20 times; $\mathrm{T}$, is total silt + clay determined by the standard sedimentation method in a non-dispersed state. Some soil properties of the study area are presented in Table 3. The results of the mechanical analysis in most of the studied soils showed a high clay and silt and low sand content. The textural classes of the soil objects were determined as clay (C), clay loam (CL) and silt loam (SiL). The high clay and silt content of study area increased disaggregation by leading to imbalances in the moisture content of different soil layers instead of aggregation. This effect may result in high runoff, soil loss and weathering processes. When the topsoil and subsoil layers are compared, the clay content of the topsoil layer decreased, the silt content was the same and the sand content increased at study site one. At study site two, the higher clay and lower silt contents were detected more in the subsoil than in the topsoil. The same result was observed for study site three. Textural differences between the topsoil and subsoil created moisture differences in the soil layers and this situation may result in large mass movements. In the study area, the coarse material varied between 4.2 and $31.0 \%$, depending on the mass transportation.

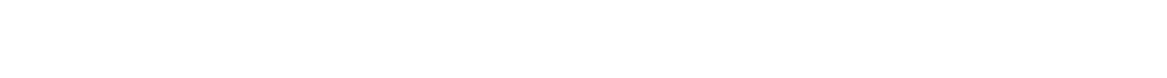


Nat. Hazards Earth Syst. Sci. Discuss., https://doi.org/10.5194/nhess-2018-13

Manuscript under review for journal Nat. Hazards Earth Syst. Sci.

Discussion started: 23 January 2018

(c) Author(s) 2018. CC BY 4.0 License.

To evaluate the forces on the soil resistance to the mass movement of the study area, aggregate stability and dispersion ratio indexes were used. The aggregate stability of the soil objects was under $46.2 \%$ and showed low aggregate stability with a high risk of soil movement. The dispersion ratio index indicated a sharp boundary between erodible and non-erodible soils, since a dispersion ratio greater than 10 indicated erodible soils and less than 10 indicated non-erodible soils. The dispersion values of the study area were greater than 10 with high erosion risk.

\subsection{D Ground Control Points}

A total of eight 3D GCPs were used in the study area. The GCPs were placed in a way so that they could be easily seen in photos taken from above, near the landslide site, but where future landslides would not affect them (Figure 5). All GCPs were placed as concrete blocks, which were topped with side wings with dimensions of $40 \times 15 \mathrm{~cm}$ so they could be easily detected in the computer environment. The geometrical distribution of the GCPs in the study area is given in Figure 6.

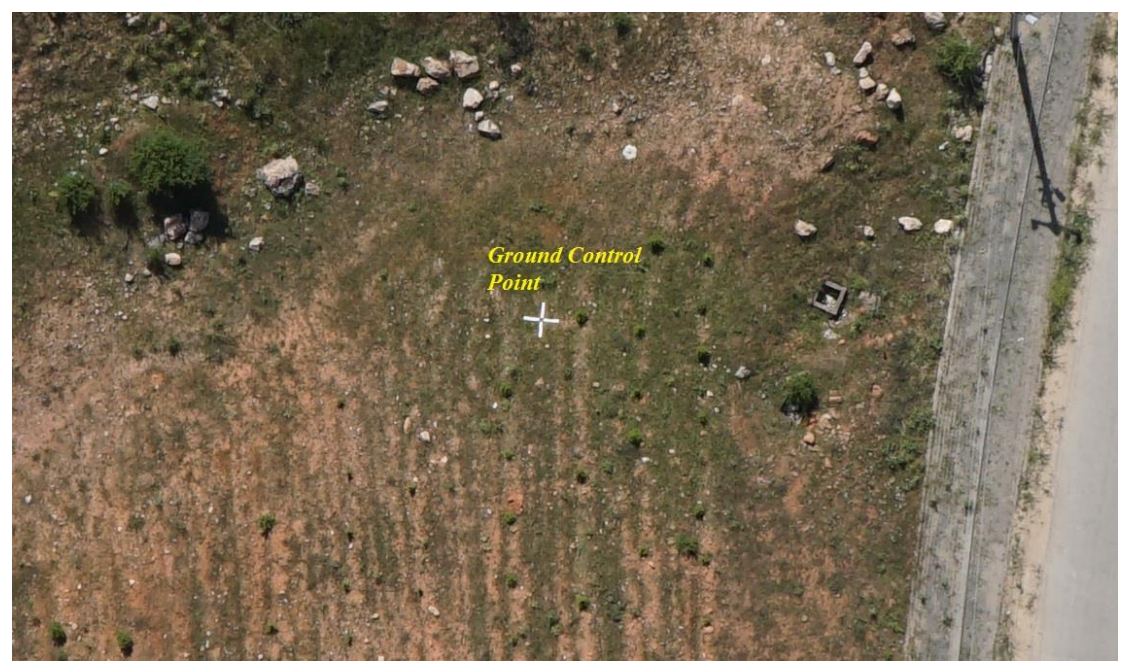

Figure 5. Ground Control Point (GCP)

The 3D positional information of the GCPs was collected by the CORS-TR System (Mekik et al., 2011) using Topcon GR3 dual-frequency GNSS (Global Navigation Satellite System) receivers. GNSS data was collected for a minimum of two hours for each point and it was computed via static analysis at the datum of ITRF96 and epoch of 2005.00. With the dual-frequency receivers used, the horizontal sensitivity of the GCPs were found to be $\pm 3 \mathrm{~mm}+0.5 \mathrm{ppm}$, while the vertical sensitivity was found to be $\pm 5 \mathrm{~mm}+0.5 \mathrm{ppm}$. 
Nat. Hazards Earth Syst. Sci. Discuss., https://doi.org/10.5194/nhess-2018-13

Manuscript under review for journal Nat. Hazards Earth Syst. Sci.

Discussion started: 23 January 2018

(c) Author(s) 2018. CC BY 4.0 License.

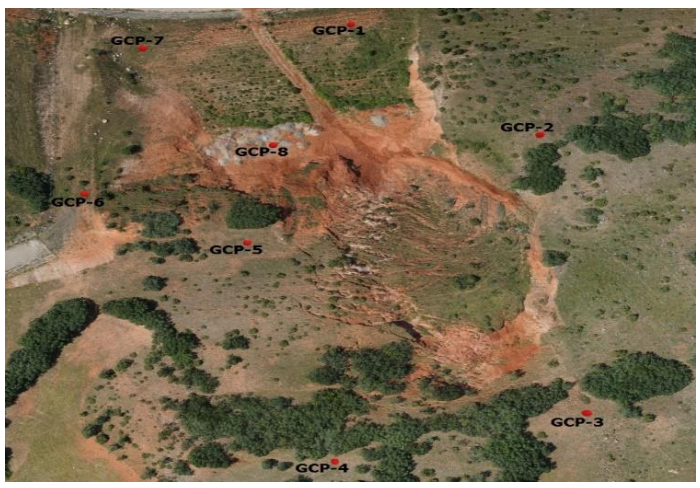

Figure 6. The geometric distribution of GCPs

\subsection{Flight Planning and Shooting of the Photos}

Flight plans were made following the GNSS measurements of the GCPs and obtaining their coordinates via analysis. The flights were carried out at five different periods following rainfall or snowfall, where the landslide area was the most active. The flight dates and flight altitude information are given in Table 4. The flight plan for the study area was set within the Mission Planner software with vertical overlapping of $80 \%$, horizontal overlapping of $65 \%$, a flight altitude of 100 meters and flying speed of 14 $\mathrm{m} / \mathrm{sec}$. A number of overlapping images were computed for each pixel of the orthomosaics. The green areas indicated an overlap of over five images for every pixel (Figure 8) (http://ardupilot.org/planner/docs/common-history-of-ardupilot.html accessed 2017 June 3. 2017). The prepared flight plan (Figure 7a, b) was uploaded onto the UAV and the photos of the study area were obtained. The same input parameters were used in all periods for the flights and an average of 190 photos were taken. Meteorological factors were considered in shooting the aerial photos and the most suitable time periods were chosen for the flights.

Table 4. Dates of flights

\begin{tabular}{clc}
\hline Period & \multicolumn{1}{c}{ Flight Date } & Flight Altitude (m) \\
\hline 1 & February 17, 2016 & 100 \\
2 & March 22, 2016 & 100 \\
3 & April 9, 2016 & 100 \\
4 & June 10, 2016 & 100 \\
5 & July 21, 2016 & 100 \\
\hline
\end{tabular}

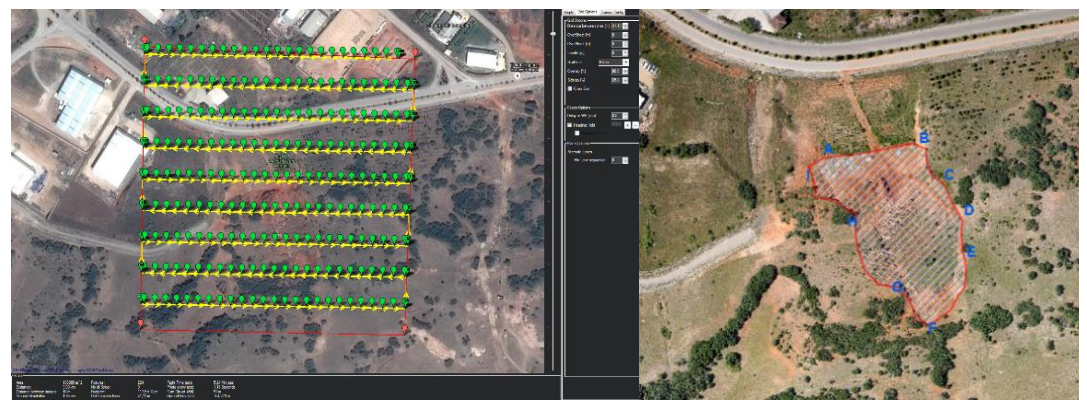


Nat. Hazards Earth Syst. Sci. Discuss., https://doi.org/10.5194/nhess-2018-13

Manuscript under review for journal Nat. Hazards Earth Syst. Sci.

Discussion started: 23 January 2018

(c) Author(s) 2018. CC BY 4.0 License.

\subsection{Point Cloud, 3D Model and Orthomosaic Production}

The photos obtained from each flight period were stored in a computer with an empty storage space of $100 \mathrm{~GB}$ and $8 \mathrm{~GB}$ of RAM. The photos were analyzed by using the Pix4D software.

In the first stage, quality checks were performed for the images, dataset, camera optimization and GCPs and these were calculated and the software produced the quality check report for each of the time periods. The Ground Sampling Distance (GSD) is the distance between two consecutive pixel centers measured on the ground. The bigger the value of the image GSD, the lower the spatial resolution of the image and the less visible details; GCPs are used to correct the geographical location of a project.

At least three GCPs are required to produce point cloud, orthomosaics and 3D models, which come from the desired datum from the photographs taken. Optimal accuracy is usually obtained with 5 - 10 GCP [22]. GCPs should also be well distributed over the data area. To orient and balance the point cloud and the 3D model, Helmert Transformation was applied. The transformation process was carried out with seven parameters, which were generated from a minimum of three GCPs and point cloud relations (Niethammer et al., 2011; Watson, 2006; Crosilla and Alberto, 2002).

In this study, the geographical location of the project was oriented and balanced through the use of eight GCPs. The RMS and GSD values of GCPs are given in Table 5.

Table 5. GCPs' mean RMS errors

\begin{tabular}{ccc}
\hline Periods & RMS $(\mathrm{mm})$ & GSD $(\mathrm{cm} / \mathrm{in})$ \\
\hline$\# 1$ & \pm 23 & $3.11 / 1.22$ \\
$\# 2$ & \pm 29 & $3.04 / 1.20$ \\
$\# 3$ & \pm 28 & $3.50 / 1.38$ \\
$\# 4$ & \pm 33 & $3.27 / 1.28$ \\
$\# 5$ & \pm 18 & $3.57 / 1.40$ \\
\hline
\end{tabular}

The second stage increased the density of 3D points of the 3D model, which were computed in the first stage. It represents the minimum number of valid re-projections of this $3 \mathrm{D}$ point to the images. Each $3 \mathrm{D}$ point must be projected correctly in at least two images. This option can be recommended for small projects, but it creates a point cloud with more noise. The minimum number of matches is three in Pix4D, as a default, but up to six can be chosen. This option reduces noise and improves the quality of the point cloud, but it can calculate fewer 3D points in the endpoint cloud.

In this project, the number of matches was taken as three. The second stage results are given in Table 6.

Table 6. Average density per $\mathrm{m}^{3}$

\begin{tabular}{ccc}
\hline Periods & Average Density $\left(\right.$ per m$\left.^{3}\right)$ & Grid DSM $(\mathrm{cm})$ \\
\hline$\# 1$ & 106.31 & 100 \\
$\# 2$ & 104.15 & 100 \\
$\# 3$ & 100.72 & 100 \\
$\# 4$ & 128.15 & 100 \\
$\# 5$ & 117.17 & 100 \\
\hline
\end{tabular}


Nat. Hazards Earth Syst. Sci. Discuss., https://doi.org/10.5194/nhess-2018-13

Manuscript under review for journal Nat. Hazards Earth Syst. Sci.

Discussion started: 23 January 2018

(c) Author(s) 2018. CC BY 4.0 License.
Natural Hazards

and Earth System

Sciences

Discussions
In the third stage, a Digital Surface Model (DSM) and an orthomosaic were formed for all periods. DSM formation was achieved by the triangulation method with $100 \mathrm{~cm}$ grid intervals. The aspect maps, showing the landslide motion direction for the first and last periods, were derived by using the DSMs of periods 1 and 5. The differences between these maps can be seen, especially in the western and northern areas (Figure 8). This means that there was a movement between periods.

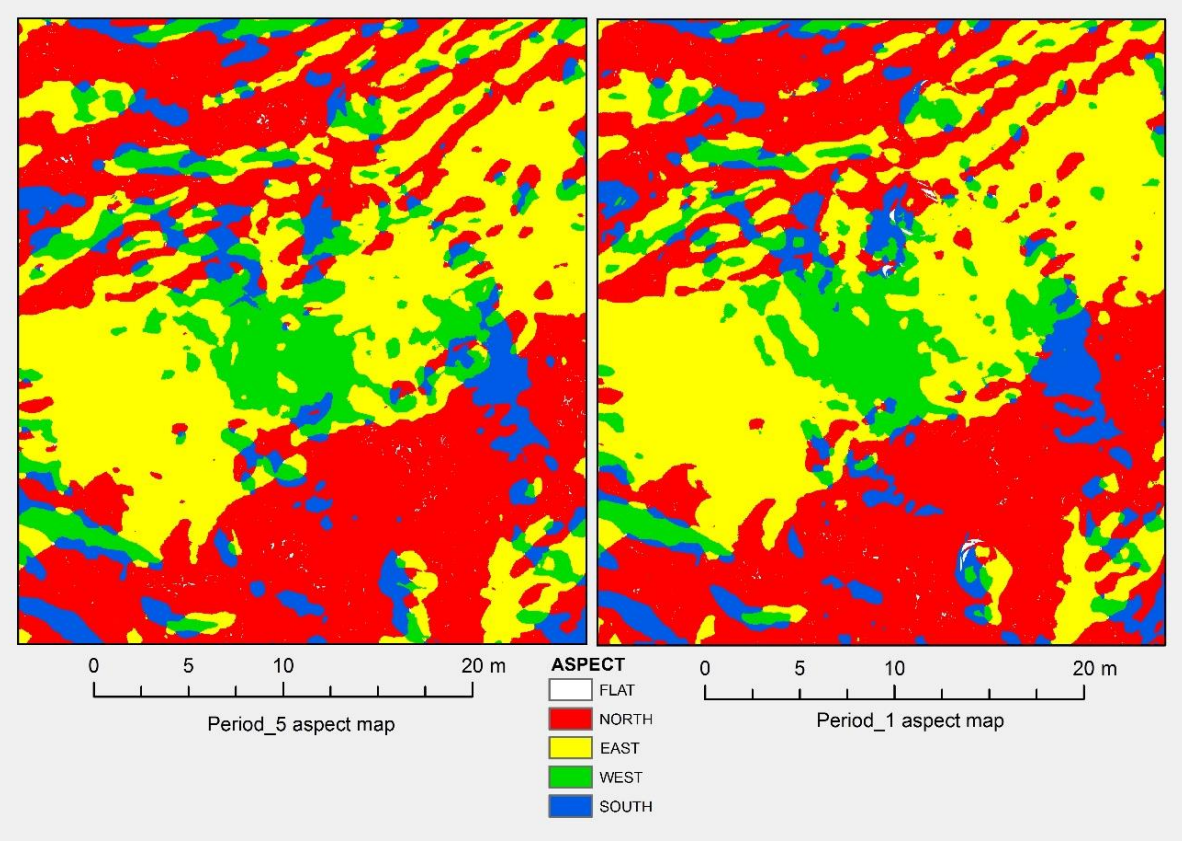

Figure 8. Aspect maps of period 5 (left) and 1 (right).

\subsection{Analysis of the Point Clouds, 3D Models and Orthomosaics}

Seventy-three object points were determined in the study area in order to monitor the speed and direction of the landslide movement (Figure 9). These points, which represent the topography, were chosen from the clearly visible details in the model and the field. 
Nat. Hazards Earth Syst. Sci. Discuss., https://doi.org/10.5194/nhess-2018-13

Manuscript under review for journal Nat. Hazards Earth Syst. Sci.

Discussion started: 23 January 2018

(c) Author(s) 2018. CC BY 4.0 License.

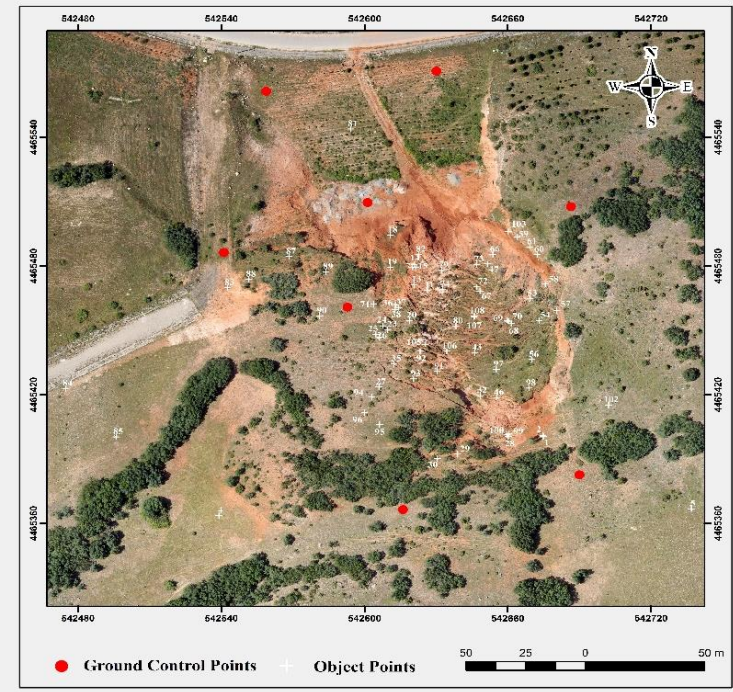

Figure 9. Ground Control and Object points

The 3D position information, orthomosaics and DSMs of the object points were produced in each period. The 3D position data were compared consecutively. As a result of these comparisons, differential displacements were calculated between T2 and T1, T3 and T2, T4 and T3, T5 and T4, and are given in Figures 10, 11, 12 and 13. Additionally, Figure 14 provides a diagram showing the two-dimensional position shift $(\Delta \mathrm{s})$ and height $(\Delta \mathrm{H})$ changes between T5 and T1 (the last and the first periods).

According to these diagrams and Table 7:

a) Points shown with a star (*) are at the centre of the area of motion and their positional displacement is higher than the median value $(>21 \mathrm{~cm})$,

b) Points shown without a star are outside the landslide area and their positional and height displacement values are lower than the median value $(<21 \mathrm{~cm})$.

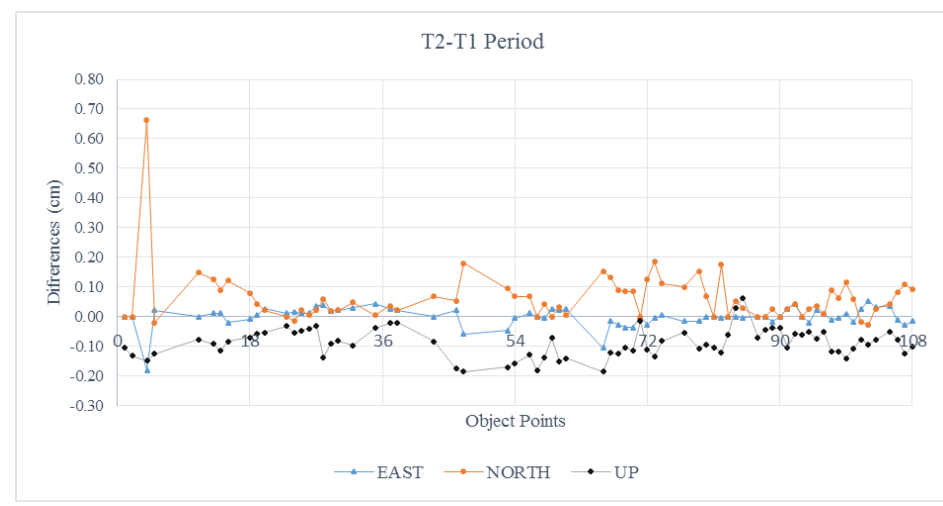

Figure 10. T2-T1 period differences 
Nat. Hazards Earth Syst. Sci. Discuss., https://doi.org/10.5194/nhess-2018-13

Manuscript under review for journal Nat. Hazards Earth Syst. Sci.

Discussion started: 23 January 2018

(c) Author(s) 2018. CC BY 4.0 License.

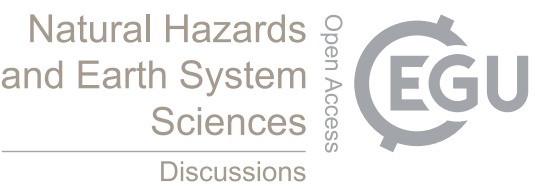

(c) (1)

88

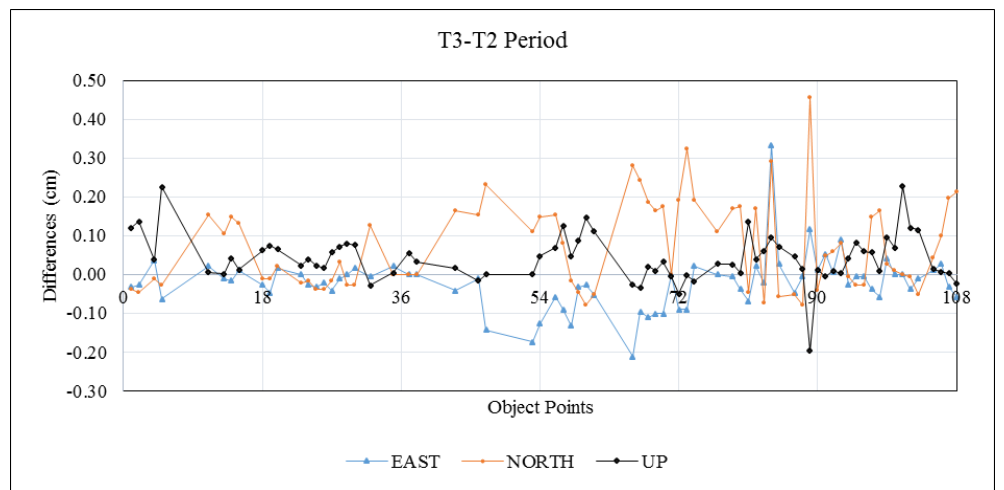

Figure 11. T3-T2 period differences

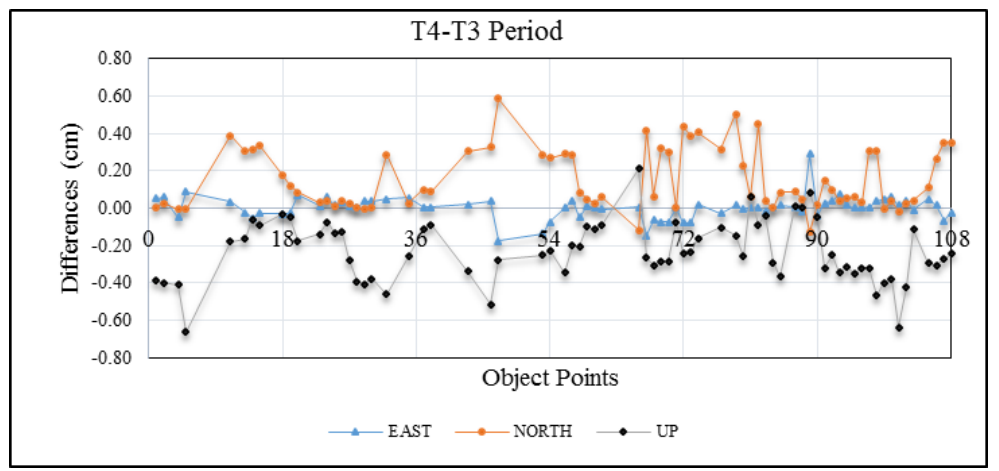

Figure 12. T4-T3 period differences

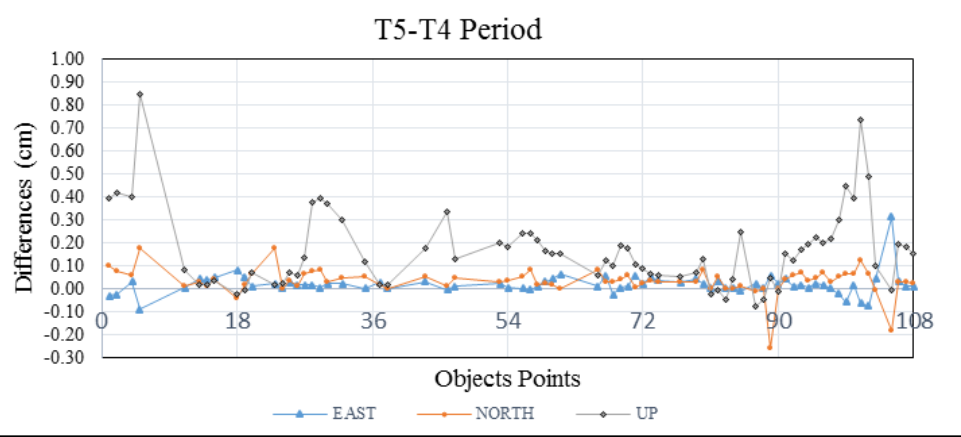

Figure 13. T5-T4 period differences 
Nat. Hazards Earth Syst. Sci. Discuss., https://doi.org/10.5194/nhess-2018-13

Manuscript under review for journal Nat. Hazards Earth Syst. Sci.

Discussion started: 23 January 2018

(c) Author(s) 2018. CC BY 4.0 License.

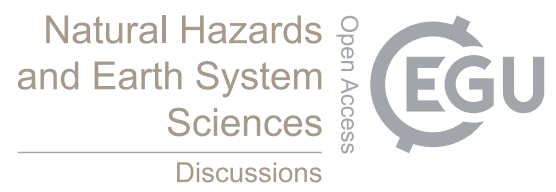

(c) (i)

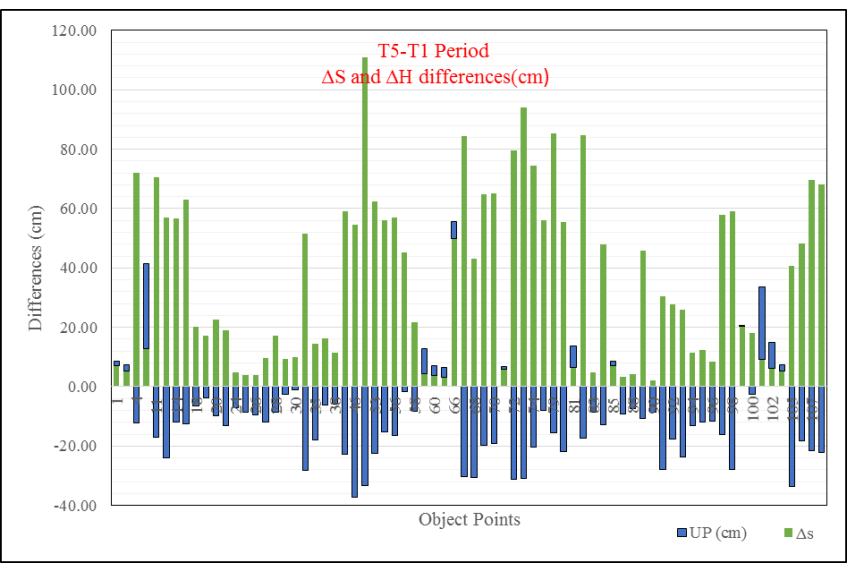

Figure 14. T5-T4 period $\Delta \mathrm{S}$ and $\Delta \mathrm{H}$ differences $(\mathrm{cm})$

The maps in Figure 8 show that the points with high positional displacement also had a change of height by $70 \%$. The positional and height displacement correlation coefficient was calculated as $\boldsymbol{\sigma}=\mathbf{0 . 7 3}$. Thus, position and height changes are highly related to each other. 
Nat. Hazards Earth Syst. Sci. Discuss., https://doi.org/10.5194/nhess-2018-13

Manuscript under review for journal Nat. Hazards Earth Syst. Sci.

Discussion started: 23 January 2018

(c) Author(s) 2018. CC BY 4.0 License.

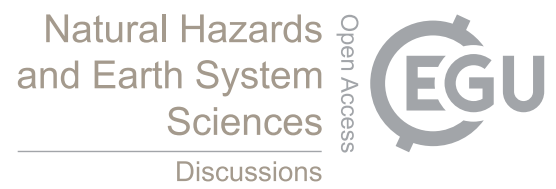

(c) (i)

347

Table 7. Vertical and horizontal motion magnitudes $(\mathrm{cm})$ of the points

\begin{tabular}{|c|c|c|c|c|c|}
\hline \multicolumn{3}{|c|}{ Bigger than median movement value $(>21 \mathrm{~cm})$} & \multicolumn{3}{|c|}{ Smaller than median movement value $(<21 \mathrm{~cm})$} \\
\hline $\begin{array}{c}\text { Number of Object } \\
\text { Points }\end{array}$ & $\begin{array}{c}\text { Movement of } \Delta s \\
\text { (cm) }\end{array}$ & $\begin{array}{l}\text { Movement UP } \\
\text { (cm) }\end{array}$ & $\begin{array}{c}\text { Number of Object } \\
\text { Points }\end{array}$ & $\begin{array}{l}\text { Movement of } \Delta s \\
\quad(\mathrm{~cm})\end{array}$ & $\begin{array}{l}\text { Movement UP } \\
(\mathbf{c m})\end{array}$ \\
\hline $47^{*}$ & 111.0 & 33.2 & 18 & 20.3 & 6.4 \\
\hline $73 *$ & 94.0 & 31.0 & 23 & 19.0 & 13.3 \\
\hline $79 *$ & 85.3 & 15.5 & 100 & 18.0 & 2.5 \\
\hline $82 *$ & 84.8 & 17.4 & 28 & 17.2 & 8.6 \\
\hline $67 *$ & 84.4 & 30.2 & 19 & 17.1 & 3.8 \\
\hline $72 *$ & 79.7 & 31.2 & 37 & 16.4 & 6.3 \\
\hline $74 *$ & 74.6 & 20.3 & 35 & 14.5 & 17.8 \\
\hline $4^{*}$ & 72.1 & 12.2 & 5 & 12.9 & 5.0 \\
\hline $11^{*}$ & 70.6 & 17.1 & 95 & 12.2 & 12.0 \\
\hline $107 *$ & 69.7 & 21.7 & 94 & 11.4 & 13.2 \\
\hline $108^{*}$ & 68.2 & 22.1 & 38 & 11.4 & 5.8 \\
\hline $70 *$ & 65.1 & 19.2 & 30 & 9.9 & 1.1 \\
\hline $69 *$ & 64.8 & 19.6 & 27 & 9.8 & 12.0 \\
\hline $15^{*}$ & 63.0 & 12.5 & 29 & 9.5 & 2.5 \\
\hline $53^{*}$ & 62.4 & 22.4 & 101 & 9.1 & 5.0 \\
\hline $43^{*}$ & 59.1 & 22.9 & 96 & 8.5 & 11.6 \\
\hline $98 *$ & 58.9 & 27.8 & 77 & 8.0 & 8.0 \\
\hline $97 *$ & 57.8 & 16.1 & 85 & 7.2 & $\begin{array}{l}1.5 \\
\end{array}$ \\
\hline $13 *$ & 57.0 & 24.0 & 1 & 7.0 & 1.6 \\
\hline $56^{*}$ & 56.8 & 16.6 & 81 & 6.4 & 7.2 \\
\hline $14 *$ & 56.7 & 11.9 & 102 & 6.2 & 8.7 \\
\hline $54 *$ & 56.1 & 15.3 & 71 & 5.8 & 1.0 \\
\hline $80^{*}$ & 55.6 & 21.9 & 103 & 5.4 & 1.8 \\
\hline $46^{*}$ & 54.7 & 37.3 & 2 & 5.3 & 2.0 \\
\hline 32 & 51.6 & 28.2 & 66 & 5.0 & 5.6 \\
\hline 106 & 48.3 & 18.1 & 83 & 4.9 & 8.7 \\
\hline 84 & 47.9 & 13.0 & 24 & 4.8 & 7.2 \\
\hline 89 & 45.7 & 10.6 & 59 & 4.3 & 8.4 \\
\hline 57 & 45.3 & 1.7 & 88 & 4.1 & $\begin{array}{l}7.7 \\
7.5\end{array}$ \\
\hline 68 & 43.0 & 30.7 & 26 & 4.0 & 9.4 \\
\hline 105 & 40.8 & 33.8 & 25 & 3.8 & 8.6 \\
\hline 91 & 30.3 & 27.8 & 60 & 3.7 & 3.4 \\
\hline $93 *$ & 26.0 & 23.6 & 87 & 3.4 & 9.2 \\
\hline $20 *$ & 22.6 & 9.7 & 61 & 3.2 & 3.1 \\
\hline
\end{tabular}

349

350

351

352

353

354

355

356

357

358

359

360

361

As a result of the positional movements obtained in the landslide area, point velocity vectors $(V x, V y, V z)$ were calculated using Equation 2 below, and they are given in Table 8. It was found that the general characteristic surface movement of the landslide took place in the north-south direction (Figure 15).

Here:

$$
V\{x, y, z\}=\frac{\Delta V\{x, y, z\}}{\Delta t} * 365
$$

$\Delta t$ : T5-T1 periods time difference,

$\Delta V\{x, y, z\}:$ The difference between Cartesian coordinate components between the $\mathrm{T} 5$ and T1 periods. 
Nat. Hazards Earth Syst. Sci. Discuss., https://doi.org/10.5194/nhess-2018-13

Manuscript under review for journal Nat. Hazards Earth Syst. Sci.

Discussion started: 23 January 2018

(c) Author(s) 2018. CC BY 4.0 License.

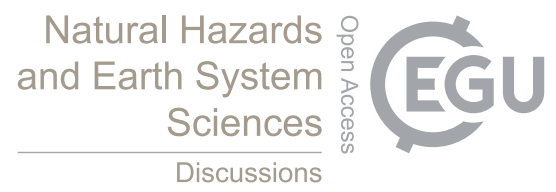

(c) (1)

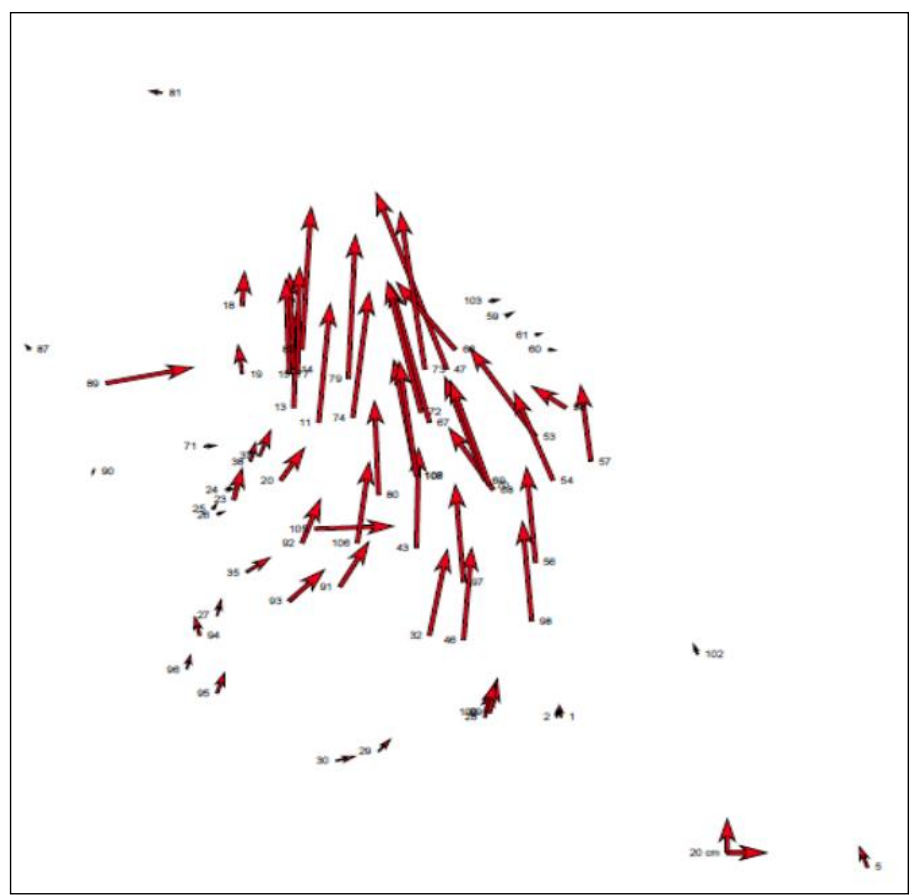

Figure 15. Characteristic surface movement of the landslide (m/year) 
Nat. Hazards Earth Syst. Sci. Discuss., https://doi.org/10.5194/nhess-2018-13

Manuscript under review for journal Nat. Hazards Earth Syst. Sci.

Discussion started: 23 January 2018

(c) Author(s) 2018. CC BY 4.0 License.
Natural Hazards and Earth System Sciences

Discussions

(c) $($ P)

Table 8 . Object points annual velocity vectors

\begin{tabular}{|c|c|c|c|c|c|c|c|}
\hline $\begin{array}{c}\text { \#Object } \\
\text { No }\end{array}$ & $V x(m / y e a r)$ & Vy (m/year) & $V z($ m/year $)$ & $\begin{array}{c}\text { \#Object } \\
\text { No }\end{array}$ & $V x$ (m/year) & $V y$ (m/year) & $V z($ m/year $)$ \\
\hline 1 & -0.068 & -0.095 & 0.219 & 68 & -0.851 & -1.605 & 0.279 \\
\hline 2 & -0.064 & -0.023 & 0.186 & 69 & -1.111 & -1.700 & 1.189 \\
\hline 4 & -1.214 & -1.568 & 1.593 & 70 & -1.122 & -1.685 & 1.212 \\
\hline 5 & 0.474 & 0.171 & 0.966 & 71 & -0.108 & 0.172 & 0.036 \\
\hline 11 & -1.767 & -1.035 & 1.480 & 72 & -1.721 & -2.010 & 1.362 \\
\hline 13 & -1.583 & -1.084 & 0.968 & 73 & -2.095 & -2.077 & 1.772 \\
\hline 14 & -1.241 & -0.996 & 1.233 & 74 & -1.955 & -1.063 & 1.505 \\
\hline 15 & -1.435 & -1.001 & 1.387 & 77 & -1.159 & -0.913 & 1.306 \\
\hline 18 & -0.530 & -0.333 & 0.392 & 79 & -1.958 & -1.268 & 1.908 \\
\hline 19 & -0.346 & -0.343 & 0.364 & 80 & -1.434 & -1.139 & 0.981 \\
\hline 20 & -0.804 & -0.064 & 0.285 & 81 & 0.265 & -0.079 & 0.191 \\
\hline 23 & -0.707 & -0.335 & 0.192 & 82 & -2.009 & -1.260 & 1.853 \\
\hline 24 & -0.261 & 0.013 & -0.148 & 83 & -0.052 & -0.177 & -0.293 \\
\hline 25 & -0.284 & -0.118 & -0.109 & 84 & -1.588 & 0.275 & 0.615 \\
\hline 26 & -0.306 & -0.066 & -0.171 & 85 & -0.147 & 0.016 & 0.206 \\
\hline 27 & -0.472 & -0.255 & -0.017 & 87 & -0.200 & -0.239 & -0.136 \\
\hline 28 & -0.575 & -0.234 & 0.246 & 88 & -0.048 & -0.151 & -0.253 \\
\hline 29 & -0.311 & 0.037 & 0.133 & 89 & -1.317 & 0.964 & 0.001 \\
\hline 30 & -0.268 & 0.214 & 0.043 & 90 & -0.136 & -0.124 & -0.252 \\
\hline 32 & -1.716 & -0.857 & 0.711 & 91 & -1.379 & -0.373 & 0.073 \\
\hline 35 & -0.776 & -0.059 & -0.181 & 92 & -1.044 & -0.355 & 0.289 \\
\hline 37 & -0.534 & -0.140 & 0.263 & 93 & -1.216 & -0.108 & -0.040 \\
\hline 38 & -0.380 & -0.164 & 0.164 & 94 & -0.429 & -0.430 & -0.002 \\
\hline 43 & -1.585 & -1.112 & 1.050 & 95 & -0.544 & -0.240 & 0.037 \\
\hline 46 & -1.874 & -1.190 & 0.605 & 96 & -0.436 & -0.238 & -0.041 \\
\hline 47 & -1.863 & -2.932 & 2.036 & 97 & -1.307 & -1.136 & 1.166 \\
\hline 53 & -0.734 & -1.995 & 0.890 & 98 & -1.564 & -1.349 & 0.932 \\
\hline 54 & -0.865 & -1.497 & 1.048 & 99 & -0.437 & -0.140 & 0.537 \\
\hline 56 & -1.285 & -1.143 & 1.129 & 100 & -0.479 & -0.112 & 0.397 \\
\hline 57 & -0.747 & -0.770 & 1.154 & 101 & 0.412 & 0.206 & 0.786 \\
\hline 58 & -0.051 & -0.790 & 0.150 & 102 & 0.122 & 0.000 & 0.350 \\
\hline 59 & 0.064 & 0.208 & 0.244 & 103 & -0.089 & 0.163 & 0.069 \\
\hline 60 & 0.007 & 0.165 & 0.063 & 105 & -1.587 & 0.589 & -0.723 \\
\hline 61 & -0.014 & 0.123 & 0.095 & 106 & -1.385 & -0.747 & 0.862 \\
\hline 66 & 0.018 & -1.281 & 1.183 & 107 & -1.472 & -1.579 & 1.336 \\
\hline 67 & -1.722 & -2.124 & 1.498 & 108 & -1.519 & -1.493 & 1.297 \\
\hline
\end{tabular}

390

391

392

393

394

395

396

\section{Results and Conclusions}

As a result of this study, we found that unmanned aerial vehicles have undeniable advantages in disaster management and they have clear benefits over other methods. The monitoring process must be continued for taking necessary precautions in case of 
Nat. Hazards Earth Syst. Sci. Discuss., https://doi.org/10.5194/nhess-2018-13

Manuscript under review for journal Nat. Hazards Earth Syst. Sci.

Discussion started: 23 January 2018

(c) Author(s) 2018. CC BY 4.0 License.

continuity and acceleration of landslides. Monitoring the landslide velocity is not possible with conventional systems. Firstly, it is not possible to monitor an ongoing movement in areas where the ground movement is active using ground surveying methods. These movements have to be monitored by using remote measurements (remote sensing, photogrammetry and UAV). Aerial photogrammetry and remote sensing techniques are not usually preferred as they are expensive, measurements cannot be made at the desired time, and they cannot achieve the sensitivity obtained with UAVs.

This study was carried out with the aim of monitoring the landslide acceleration of movement of an area that could lead to great danger if it continues. In this study, GSD values of 3.11/1.22-3.57/1.40 cm/in were reached with a flight altitude of $100 \mathrm{~m}$. It is not possible to reach these values with manned aerial vehicles or satellite images because flight altitudes will be higher in both cases and the result of this situation will decrease the sensitivity. Thus, it was concluded that the most effective situational awareness and monitoring might be achieved by UAVs. Additionally, if it is desired to increase sensitivity in monitoring landslides, GCPs should be assigned in a suitable distribution with a suitable geometry at places that are not affected by the landslide, and the area of flight should be widened based on these GCPs.

This study shows that UAVs are important tools in determining the speeds and directions of landslide movements. In addition, landslide movements may be monitored in real time using UAVs, allowing decisions to be made and precautions to be taken. In the light of the UAV data obtained, early warning may prevent more tragic disasters and the necessary precautions can be taken. Another important issue that needs to be emphasized at the end of this study is that, with other traditional methods, the monitoring of landslides and determination of the speed and direction of movement in real time is impossible.

\section{References}

Turner, D., Lucieer, A., DeJong, S.M., "Time series analysis of landslide dynamics using an Unmanned Aerial Vehicle (UAV)”, Remote Sensing. 2015, 7: 1736-1757. 2015.

Nadim, F., Kjekstad, O., Peduzzi, P., et al. "Global landslide and avalanchehotspots" Landslides. 3: 159-173, 2006.

Dikau, R., Brunsden, D., Schrott, L., et al. "Landslide recognition. Identification, movement and causes". John Wiley and Sons., 1996.

Lucier, A., Jong, S.M., Turner, D., "Mapping landslide displacements using structure from motion (SfM) and image correlation of multi-temporal UAV photography". Progress in Physical Geography. 38: 97-116. 2014.

Niethammer, U., Rothmund, S., James, M.R., Travelletti, J., \& Joswig, M., "UAV based remote sensing of landslides". In proceedings of the International Archives of Photogrammetry, remote Sensing and Spatial Information Sciences, Commission V Symposium; 2010 June 21-24; Newcastle Upon Tyne. 2010.

Mantovani, F., Soeters, R., Van Westen, C.J., "Remote sensing techniques for land slide studies and hazard zonation in Europe". Geomorphology, 2016, Volume 15(3-4): 213-225. 1996.

Rau, J.Y., Jhan, J.P., Lo, C.F., Lin, Y.S., "Landslide mapping using imagery acquired by a fixed -wing $U A V$ ". International Archives of Photogrammetry Remote Sensing and 
Nat. Hazards Earth Syst. Sci. Discuss., https://doi.org/10.5194/nhess-2018-13

Manuscript under review for journal Nat. Hazards Earth Syst. Sci.

Discussion started: 23 January 2018

(C) Author(s) 2018. CC BY 4.0 License.
Natural Hazards

and Earth System

Sciences

Discussions
442

443

444

445

446

447

448

449

450

451

452

453

454

455

456

457

458

459

460

461

462

463

464

465

466

467

468

469

470

471

472

473

474

475

476

477

478

479

480
Spatial Information Sciences, Volume XXXVIII-1/C22, Proceedings of ISPRS Workshop; 2011 September 14-16; Zurich. 2011.

Saripalli, S., Montgomery, J.F., Sukhatme, G.S., "Visualy guided landing of an unmanned aerial vehicle". IEEE Transaction on Robotics and Automation. 2003 June 19: 371-380. 2003.

Tahar, K., Ahmad, A., Akib, W.A., Udin, W.S., "Unmanned Aerial Vehicle technology for large scale mapping”. ISG\&ISPRS Conference; 2011 May 10-11; Munich. 2011.

Hunt, R., Hively, D., Fujikawa, S.J., Linden, D., Daughtry, C. \& Mc Carty, G., "Acquisition of NIR-Green-Blue Digital Photographs from Unmanned Aircraft for Crop Monitoring”, Remote Sensing. 2: 290-305. 2010.

Eisenbeiss, H., "UAV Photogrammetry. Dissertation". Institute of Geodesy and Photogrammetry. Zurich: University of Technology. 2009.

Nagai, M., Chen, T., Ahmed, A., \& Shibasaki, R., "UAV borne mapping by multi sensor integration", The International Archives of the Photogrammetry, Remote Sensing and Spatial Information Sciences, Vol. XXXVII, Part B1, 2008 July 3-11Beijing. 2008.

Nex, F., Remondino, F., "UAV for $3 D$ mapping applications: A review", Appl. Geomatics. 6: 1-15. DOI:10.1007/s12518-013-0120-x. 2014.

Sumengen, M., "Turkish 1/100000 scaled geological map reports", General Directorate of Mineral Research, Ankara.[In Turkish]. 1998.

Gee, G.W., Bauder, J.W., "Particle size analysis. In methods of soil analysis." Part 1, 2nd ed. A. Klute; 383-411. 1986.

Middleton, H.E., "Properties of some soil which influence soil erosion". USDA TECH. Bull: 178, 1930.

Yoder, R.E., "A direct method of aggregate analysis of soils and a study of the physical nature of erosion losses". J. Am. Soc. Agric. 28: 337-351. 1936.

Mekik, C., Yildirim, O., Bakici, S., "The Turkish real time kinematic GPS network (TUSAGA-Aktif) infrastructure”. Scientific Research and Essays. 6.19: 3986-3999. 2011.

Niethammer, U., Rothmund, S., Schwaderer, U., Zeman, J., Joswig, M., "Opensource lmage processing tools for low cost UAV based landslide investigations". In Proceedings of the International Archives of Photogrammetry, Remote Sensing and Spatial Information Sciences, ISPRS, 2011 September 14-16; Zurich, 2011.

Watson, G.A., "Computing helmert transformations". Journal of Computational and Applied Mathematics, 197:2: 387-394. 2006.

Crosilla, F., and Alberto, B., "Use of generalised procrustes analysis for the photogrammetric block adjustment by independent models". ISPRS Journal of Photogrammetry and Remote Sensing. 56: 195-209. 2002. 